\title{
PEMANFAATAN PRIVATE CLOUD STORAGE SEBAGAI MEDIA PENYIMPANAN DATA E-LEARNING PADA LEMBAGA PENDIDIKAN
}

\author{
Irfan Santiko ${ }^{1}$, Rahman Rosidi ${ }^{2}$, Seta Agung Wibawa ${ }^{3}$ \\ ${ }^{1,2}$ STMIK AMIKOM Purwokerto; Jln.Let.Jend.Pol. Sumarto, Purwanegara, Watumas \\ Program Studi Sistem Informasi STMIK AMIKOM Purwokerto \\ Email: 1irfan.santiko@amikompurwokerto.ac.id; 2amang@amikompurwokerto.ac.id \\ ${ }^{3}$ setaagungw@gmail.com
}

\begin{abstract}
ABSTRAK
Cloud Storage merupakan beberapa sistem virtual yang ada dalam 1 PC server fisik, dan server virtual ini bisa menjalankan bermacam-macam fungsi server yang berbeda, misal fungsi server DNS, server Oracle, dan server 2 lainnya, jadi hemat tempat, dan listrik, serta hardware-nya jadi semakin sedikit karena 1 server bisa menjalankan bermacam-macam server yang berbeda dan itu terpisah. Ada banyak layanan cloud yang sering para pengguna online manfaatkan seperti own cloud, google drive, dropbox, dan lainnya. Pada kasus ini penulis mencoba menerapkan ke dalam e-learning. Seperti yang diketahui bahwa e-learning merupakan sistem pembelajaran yang menggunakan teknologi khususnya web, dimana media penyimpanan ada dalam sebuah wadah server dengan kapasitas tertentu. Banyaknya provider yang memberikan penawaran kepada lembaga pendidikan untuk menyediakan jasa penyimpanan yang cukup memakan biaya tinggi membuat proses menjadi terkendala. Pada akhirnya $e$ learning sendiri tidak berjalan secara maksimal. Dengan penelitian ini, akan memberikan sebuah jawaban yaitu dengan hasil perancangan yang disesuaikan dengan kondisi dan requirement yang ada pada lembaga pendidikan tersebut, diharapkan tidak menghambat kinerja performa $e$-learning yang mereka miliki. Beberapa faktor yang diujikan nantinya adalah dari sisi akurasi, kecepatan akses, kapasitas, keamanan, dan berujung pada efektifitas biaya yang dibandingkan dengan provider tawarkan.
\end{abstract}

Kata Kunci: Implementasi, Cloud, Server, E-Learning

\begin{abstract}
Cloud Storage is a virtual system that exists on a single physical PC server, and this virtual server can run a variety of different server functions, such as DNS server functions, Oracle servers, and other 2 servers, saving space, electricity power and hardware were lesser because 1 server can run a variety of different servers and it is separated. There are many cloud services that are often used online users such as own cloud, google drive, dropbox, and others. In this case the author tries to apply into e-learning. As is known that e-learning is a learning system that uses technology, especially web, where the storage media is in a container server with a certain capacity. The large number of providers that offer educational institutions to provide costly storage services makes the process quite constrained. In the end the e-learning is not running optimally. This research will give an answer that is with the result of design that is adjusted to condition and requirement that exist in educational institution, is expected not hampering performance performance of e-learning that they have. Some of the factors that will be tested later in terms of accuracy, speed of access, capacity, and culminate in cost effectiveness compared to the provider offer.
\end{abstract}

Keywords: Implementation, Cloud, Server, E-Learning

DOI: $10.15408 /$ jti.v10i2.6992 


\section{PENDAHULUAN}

Cloud Computing atau komputasi awan adalah gabungan pemanfaatan teknologi komputer ('komputasi') dan pengembangan berbasis Internet Cloud Storage. Cloud Storage adalah metafora dari internet, sebagaimana media penyimpanan yang sering digambarkan pada diagram jaringan komputer. Selain seperti awan dalam diagram jaringan komputer, Cloud Storage dalam cloud computing juga merupakan abstraksi dari infrastuktur kompleks yang disembunyikannya. Cloud Computing menerapkan suatu metode komputasi, yaitu kapabilitas yang terkait teknologi informasi disajikan sebagai suatu layanan (service) sehingga pengguna dapat mengaksesnya lewat Internet tanpa mengetahui apa yang ada didalamnya, ahli dengannya, atau memiliki kendali terhadap infrastruktur teknologi yang membantunya [1].

Dengan ukuran data yang semakin hari semakin meningkat sungguh tidak relevan lagi jika memilih untuk menambah perangkat baru selain dengan harga yang relatif mahal juga kenyamanan serta kemudahan untuk dapat diakses kapan dan dimanapun akan terbatasi. Dari permasalahan tersebut didapatkan sebuah solusi yang memanfaatkan perkembangan teknologi penyimpanan di awan atau dikenal dengan istilah cloud storage. Cloud Storage atau dikenal dalam bahasa baku komputasi awan adalah sebuah layanan penyimpanan data online yang terintegrasi dan tersinkronisasi melalui internet dan dapat di akses dengan menggunakan berbagai platform (OSX, iOS, Windows, Windows Mobile, Android, Linux, Blackberry, Symbian dan lain-lain) [10].

Cloud storage memiliki banyak keuntungan dibandingkan dengan penyimpanan data secara tradisional. Data yang disimpan pada cloud storage akan dapat diakses dimana saja serta kapanpun. Cloud storage akan diintegrasikan ke berbagai perangkat untuk mendapatkan kemudahan pengaksesan seperti ke perangkat mobile (smartphone), tablet serta personal komputer. Fitur unggulan lainnya yaitu tersedianya file sharing yang memudahkan untuk berbagi file dengan pihak lain. Hal ini akan sangat memudahkan misalkan saja terlibat dalam sebuah proyek kolaboratif untuk bertukan salinan file baik secara online maupun offline. Selain itu tingkat keamanan pada cloud storage sangat baik, hal tersebut dikarenakan cloud storage menggunakan sistem private cloud. Private cloud merupakan sebuah mekanisme penyediaan resource IT secara menyeluruh, namun akan dideploy secara terpisah dari publiccloud dan hanya bisa diakses melalui jaringan private, sehingga memiliki tingkat security yang lebih baik. Model ini cocok untuk perusahaan dengan skala enterprise yang sangat memperhatikan privasi dan keamanan data [3].

E-learning merupakan sistem pembelajaran yang menggunakan teknologi khususnya web, dimana media penyimpanan ada dalam sebuah wadah server dengan kapasitas tertentu. Banyaknya provider yang memberikan penawaran kepada lembaga pendidikan untuk menyediakan jasa penyimpanan yang cukup memakan biaya tinggi membuat proses menjadi terkendala. Pada akhirnya e-learning sendiri tidak berjalan dan berfungsi secara maksimal.

Pada penelitian ini, peneliti akan memberikan sebuah solusi yang bisa di implementasikan yaitu, dengan menunjukan analisa hasil perancangan yang di sesuaikan dengan requirement yang ada pada lembaga pendidikan tersebut, diharapkan tidak menghambat kinerja performa elearning yang mereka miliki. Faktor yang di ujikan nantinya adalah dari sisi:
a. Akurasi,
b. Kecepatan akses,
c. Keamanan,
d. Kapasitas, dan
e. Efektifitas biaya.

Dengan demikian akan diperoleh sebuah analisa, bahwa implementasi cloud storage tersebut dapat di terapkan secara kondisional terhadap kemampuan atau requirement lembaga pendidikan yang menggunakan elearning tersebut tanpa harus mempertimbangkan secara berlebihan.

\section{TINJAUAN PUSTAKA}

Penerapan Mobile Augmented Reality Berbasis Cloud Computing yaitu menggabungkan dua teknologi berupa Mobile Augmented Reality (MAR) dengan Cloud Computing untuk menyajikan sebuah realitas tertambah pada media cetak Harian Umum Radar Banyumas. Penggabungan teknologi menggunakan metode markers complex untuk mengenali objek menghasilkan sebuah konten Mobile Augmented Reality (MAR), sehingga 
pada ponsel akan menghadirkan keterangan tentang berita atau bahkan menampilkan gambar, suara dan video. Pembaca cukup mengaktifkan aplikasi, kemudian mengarahkan smartphone ke objek gambar pada media cetak dan dari objek tersebut akan muncul gambar, animasi atau video serta audio pendukung lainnya [4].

Research on Mobile Cloud Computing: Review, Trend and Perspectives" yang menggabungkan mobile computing dan cloud computing. Tujuannya adalah menyajikan sebuah ulasan mengenai latar belakang dan prinsip Mobile Cloud Computing, karakteristik, tren saat ini dan tren masa depan. Dari penelitian ini dapat disajikan tentang karakteristik, analisa fitur dan infrastruktur Mobile Cloud Computing serta menunjukkan peluang untuk penelitian masa depan [6].

Pemanfaatan Cloud Storage Sebagai Media Penyimpan Data Terstruktur pada Opengovernment menghasilkan kesimpulan berupa penggunaan cloud storage sebagai media penyimpanan data sangatlah bermanfaat untuk mempermudah penyimpanan serta kemudahan untuk dapat diakses dimanapun yang tersinkonisasikan keberbagai perangkat seperti PC, Notebook, Tablet dan Smartphone. Cloud storage dapat diakses dimanapun dengan jaringan internet serta dapat disinkronisasikan ke berbagai device seperti smartphone dan media lainnya. Cloud storage dapat melakukan file sharing dengan pengguna lain tanpa harus bertukar alat penyimpanan seperti flashdisk. Teknologi cloud storage memberikan kemudahan pengaksesan data dimanapun sehingga tidak harus membawa alat penyimpanan data yang mempunyai resiko [5].

Desain dan Implementasi Service Oriented Architecture menggunakan Private Cloud Computing berbasis Open Source dengan pendekatan komponen Service Oriented Architecture mampu menyediakan antarmuka yang efisien untuk proses bisnis perusahaan dapat diakses menggunakan Fixed Device dan Mobile Device seperti Smartphone Android, Komputer Pad, dan PC Tablet melalui koneksi jaringan lokal dan internet. Beberapa tantangan yang harus dihadapi dalam mengimplementasikan teknologi private cloud computing diantaranya adalah masalah keamanan komputasi dan kapasitas Bandwidth, namun sebagian teratasi karena menggunakan akses jaringan internal yaitu LAN (Local Area Network) [9].

\begin{abstract}
Konsep dan penerapan Cloud Computing untuk meningkatkan mutu pembelajaran mengemukanan bahwa dengan teknologi cloud computing dapat menjadi evaluasi terkini dalam meningkatkan mutu pembelajaran, mutu informasi, serta dapat mendukung seluruh kegiatan instansi Perguruan Tinggi maupun organisasi dengan lebih stabil, terkontrol dan termonitor dengan lebih baik [8].
\end{abstract}

\section{METODE PENELITIAN}

Metodologi yang digunakan dalam perancangan sistem adalah metode incremental. Yang dimaksud dengan model incremental adalah "The incremental build life cycle model provides for progressive development of operational software, with each release providing added capabilities". Incremental model merupakan metode dimana produk didesain, diimplementasikan, dan diuji secara bertahap (setiap modul akan ditambahkan bertahap) hingga produk selesai [2].

Incremental Model

Requirements $>$ Design \& Development $>$ Testing $>$ Implementations

Gambar 1. Siklus incremental model

Tahapan-tahapan dalam model incremental adalah sebagai berikut:

a. Requirement

Tahapan ini menganalisis kebutuhan, analisis dilakukan berdasarkan kebutuhan user yang meliputi member, warehousing dan operational.

b. Specification

Tahapan ini menentukan spesifikasi perangkat lunak berdasarkan analisis kebutuhan yang berupa media penyimpanan bersama (share host).

\section{c. Architecture Design}

Tahapan ini merupakan perancangan arsitektur software sebelum masuk ke tahapan pengkodean pada bagian selanjutnya. Tujuan tahapan ini adalah untuk menghasilkan model dari analisa dan landasan dari tahap pengkodean.

d. Code

Code merupakan tahap pengkodean dalam pembuatan program yang meliputi pembuatan kode program, desain dan pembangunan sistem 
e. Test

Test merupakan tahap pengujian. Pengujian ini dilakukan oleh pengguna produk. Pengujian dilakukan dari sisi user interface, pengujian error, dan fitur - fitur sistem.

Untuk kerangka pikir sendiri penulis menyusun beberapa tahapan yang dilakukan dalam perancangan hingga tes/pengujian rancangan. Gambar 2 berikut adalah hasil kerangka pikir yang direncanakan:

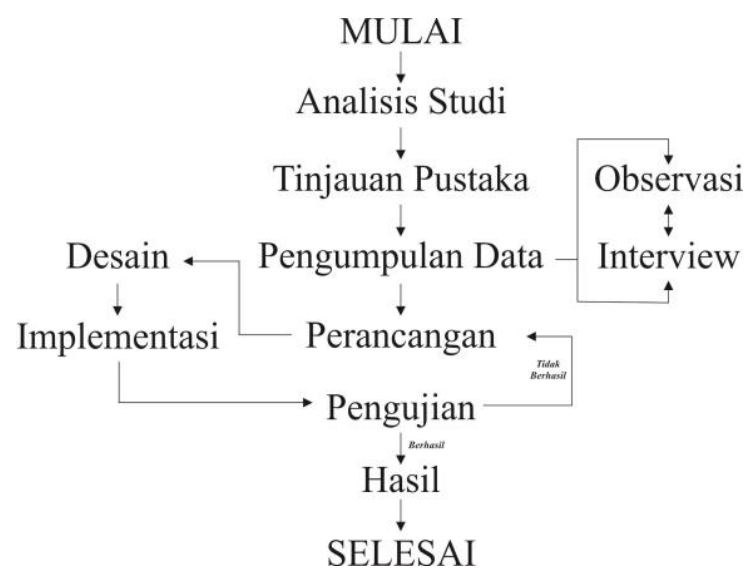

Gambar 2. Kerangka pikir penelitian

\section{HASIL DAN PEMBAHASAN}

\subsection{Analisa Kebutuhan (Requirement)}

Pada analisa kebutuhan ini, peneliti membandingkan sistem e-learning yang samasama menggunakan cloud storage dengan model sewa dan membuat sendiri. Perbandingan ini telah disusun berdasarkan aspek dari sisi akurasi, kecepatan akses, kapasitas, keamanan, dan berujung pada efektifitas biaya. Untuk lebih jelas bisa di lihat pada Tabel 1 berikut ini:

Tabel 1. Komparasi kebutuhan (requirement)

\begin{tabular}{lll}
\hline \multicolumn{1}{c}{ ASPEK } & CLOUD PUBLIK & CLOUD PRIVATE \\
\hline Akurasi & Sangat Akurat & Sangat Akurat \\
Kecepatan & Mengandalkan & Tidak Mengandalkan \\
Akses & Internet & Internet \\
Kapasitas & Terbatas & Tidak terbatas \\
Keamanan & Dikelola Provider & Dikelola Pribadi \\
Biaya & Ditetapkan & Kondisional \\
\hline
\end{tabular}

Dari analisa Tabel 1 tersebut, bisa disimpulkan bahwa kebutuhan yang ada pada cloud private lebih cenderung dapat di kondisikan sesuai dengan requirement yang ada pada lembaga pendidikan. Dalam perancangan ini ada 2 kebutuhan standar yang menjadi dasar yaitu fungsi dan non-fungsi. Untuk fungsi sendiri sebagaimana dilihat pada konsep Cloud Storage artinya bahwa sistem nanti diharapkan:

1. Dapat menyimpan segala bentuk dokumen baik itu file arsip maupun audio visual dengan kapasitas yang lebih banyak atau tidak terbatas.

2. Para pengguna mendapatkan hak akses yang aman dalam arti tidak dikelola oleh pihak ketiga atau provider.

3. Dapat berbagi dengan mudah dan dapat terintegrasi dengan komputer user (syncronize).

4. Biaya tidak terlalu menekan kepada pasar yang biasa di tawarkan oleh provider, artinya biaya tidak menjadikan performa $e$ learning berkurang hanya karena media penyimpanan yang kurang maksimal.

Sedangkan pada kebutuhan non-fungsi peneliti akan mencoba menggunakan perangkat/hardware yang biasa digunakan oleh pengguna (rekomendasi hardware) atau minimal yang sering digunakan oleh masyarakat pengguna awam, dan yang akan di gunakan adalah hardware sebagai berikut:

1. Satu buah PC Server Windows Server 2008

2. Satu buah PC Client Windows XP

3. Satu Router dan Hub LAN RC2 /UTP

4. Modem dan Koneksi Internet Min $5 \mathrm{~Gb} /$ Bulan

5. Own Cloud Storage Opensource

6. Wireless Instrument (Ethernet \& Router WiFi)

\subsection{Perancangan Model}

Pada perancangan, peneliti akan membuat sebuah perancangan yang disusun berdasarkan requirement non fungsi yang telah ditentukan pada analisa kebutuhan sebelumnya. Peneliti memilih pada posisi kebutuhan cloud private untuk digunakan dalam E-learning di karenakan dapat di kondisikan sesuai kebutuhan. Artinya apapun kondisi hardware yang ada pada lembaga pendidikan, cloud ini akan tetap berjalan pada e-learning lembaga pendidikan. 


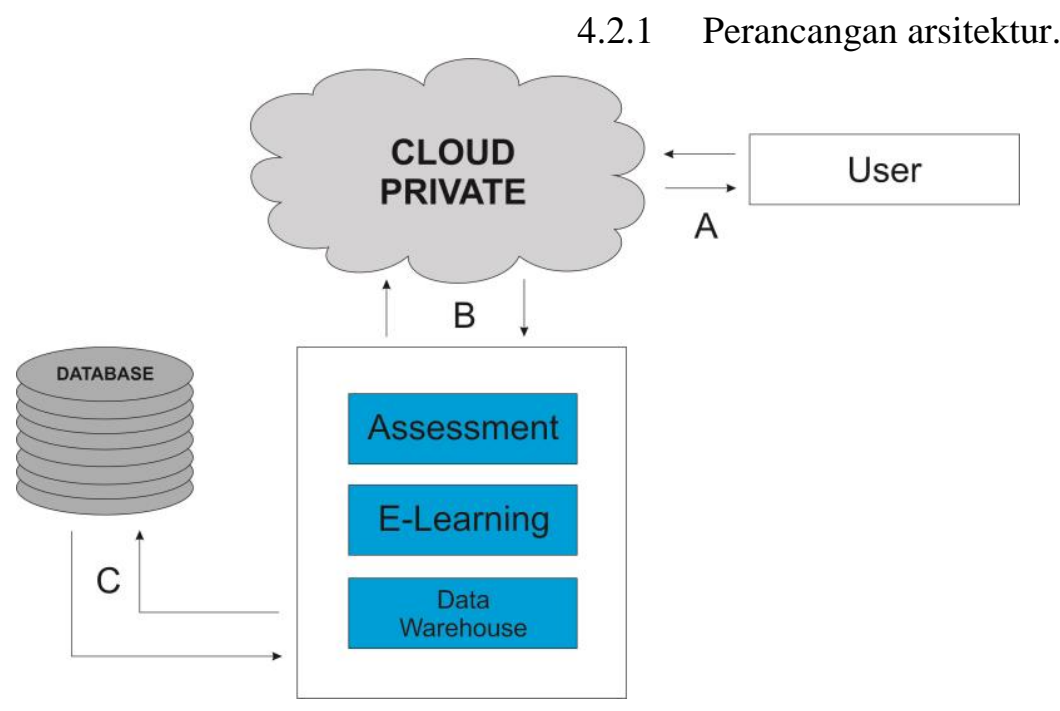

Gambar 3. Perancangan arsitektur cloud

Pada Gambar 3 tersebut berikut penjelasan tiap poin yang tertera di gambar:

A. End User atau pengguna nantinya akan mengakses 1 portal yaitu portal yang ada dalam cloud tersebut. Artinya akan mengakses cukup 1 IP saja. Di dalam cloud tersebut ada pemilah sistem yang memang sengaja dipisahkan dengan tujuan agar kestabilan akses tetap bisa optimal.

B. Bagian B ini adalah sekumpulan sistem pembelajaran/e-learning yang terdiri 3 bagian yaitu aplikasi e-learning, aplikasi warehouse (gudang data) lembaga, dan assesment/portal ujian online.

C. Bagian $\mathrm{C}$ adalah tempat untuk menyimpan seluruh data dari ketiga aplikasi di poin B tersebut.

\subsubsection{Instalasi sistem cloud}

Untuk instalasi cloud, peneliti menggunakan media opensource dari owncloud. Karena selain mudah dipahami oleh pengguna admin, tentu saja dari secure sangat private. Terlihat dari hak akses yang hanya dipegang oleh satu admin untuk melakukan konfirmasi user. Berikut ini proses instalasi owncloud:

1. Kita gunakan OS Linux untuk membangun cloud private tersebut, kemudian kita buka terminal linux.

2. Install komponen php pada terminal: yum install php-gd php-intl phpmbstring php-process php-xml

3. Masukan key repositori:

sudo rpm --import https://download.owncloud.org/downl oad /repositories/stable

/CentOS_7/repodata/repomd.xml.key

4. Dengan perintah curl, gunakan untuk mendownload repositori tersebut:

sudo curl $-\mathrm{L}$ https://download.owncloud.org/ download/repositories/stable/CentOS _7/ ce:stable.repo -o /etc/yum.repos.d/ownCloud.repo

5. Install cloud setelah didownload, dan akan muncul notifikasi berikut:

. . . Installed: owncloud.noarch 0:9.1.1-1.2 Dependency Installed: libX11.x86_64 0:1.6.3-2.el7 libX11common.noarch $0: 1.6 .3-2 . \mathrm{el} 7$ libXau.x86_64 $0: 1.0 .8-2.1 . e 17$ libXpm.x86_64 0:3.5.11-3.el7

libpng.x86_64 2:1.5.13-7.el7_2 libxcb.x86 64 $0: 1.11-4 . e l 7$ libxslt.x86 64 0:1.1.28-5.el7 owncloud-deps-php5.noarch 0:9.1.11.2 owncloud-files.noarch 0:9.1.1-1.2 php-gd.x86_64 0:5.4.16-36.3.el7_2 php-ldap.x86_64 0:5.4.16-36.3.el7_2 php-mbstring.x86_64 0:5.4.1636.3.el7_2 php-process.x86_64 0:5.4.16-36.3.el7_2 php-xml.x86_64 0:5.4.16-36.3.el7_2 t1lib.x86_64 0:5.1.2-14.el7 Complete!

6. Setelah proses selesai akses dari portal http://server_domain_or_IP/ownclo ud atau http://localhost/owncloud 


\subsubsection{Tampilan Cloud}

1. Tampilan awal owncloud.

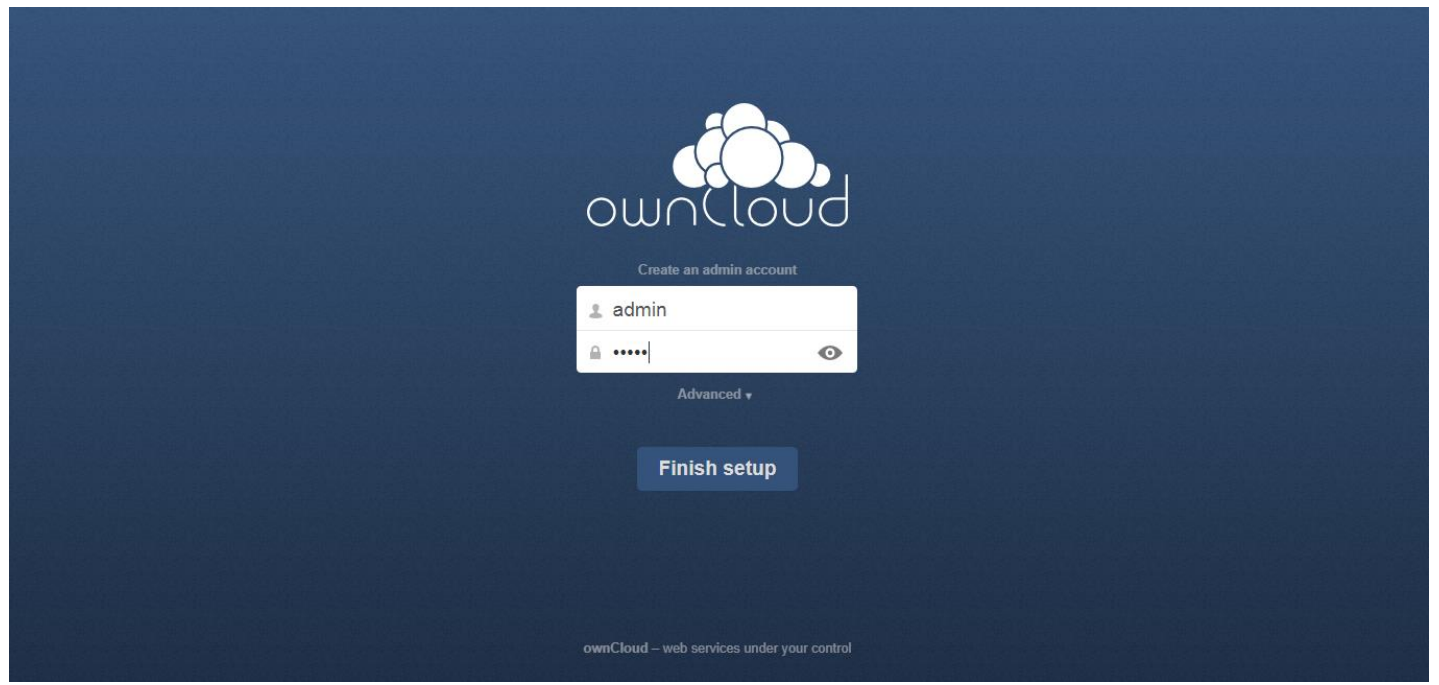

Gambar 4. Index cloud private dari owncloud

2. Tampilan Dasboard administrator owncloud

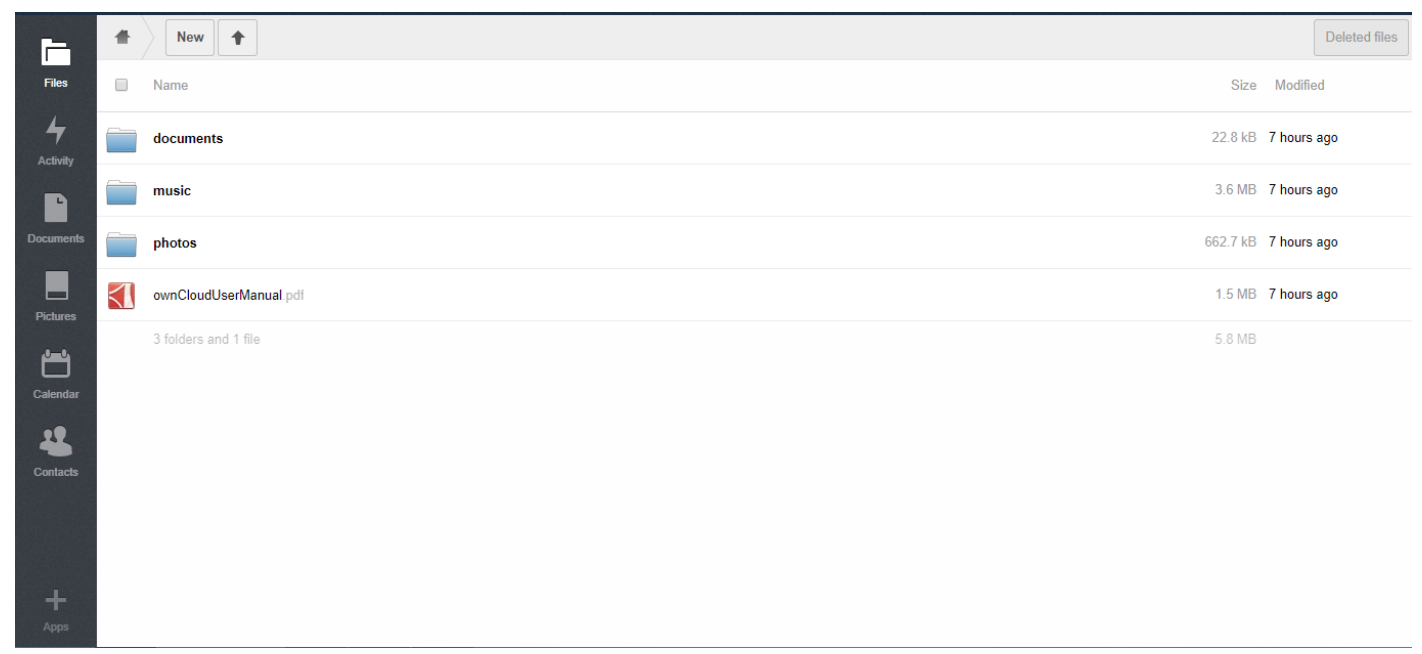

Gambar 5. Dasboar Administrator Owncloud 
3. Tampilan proses upload data

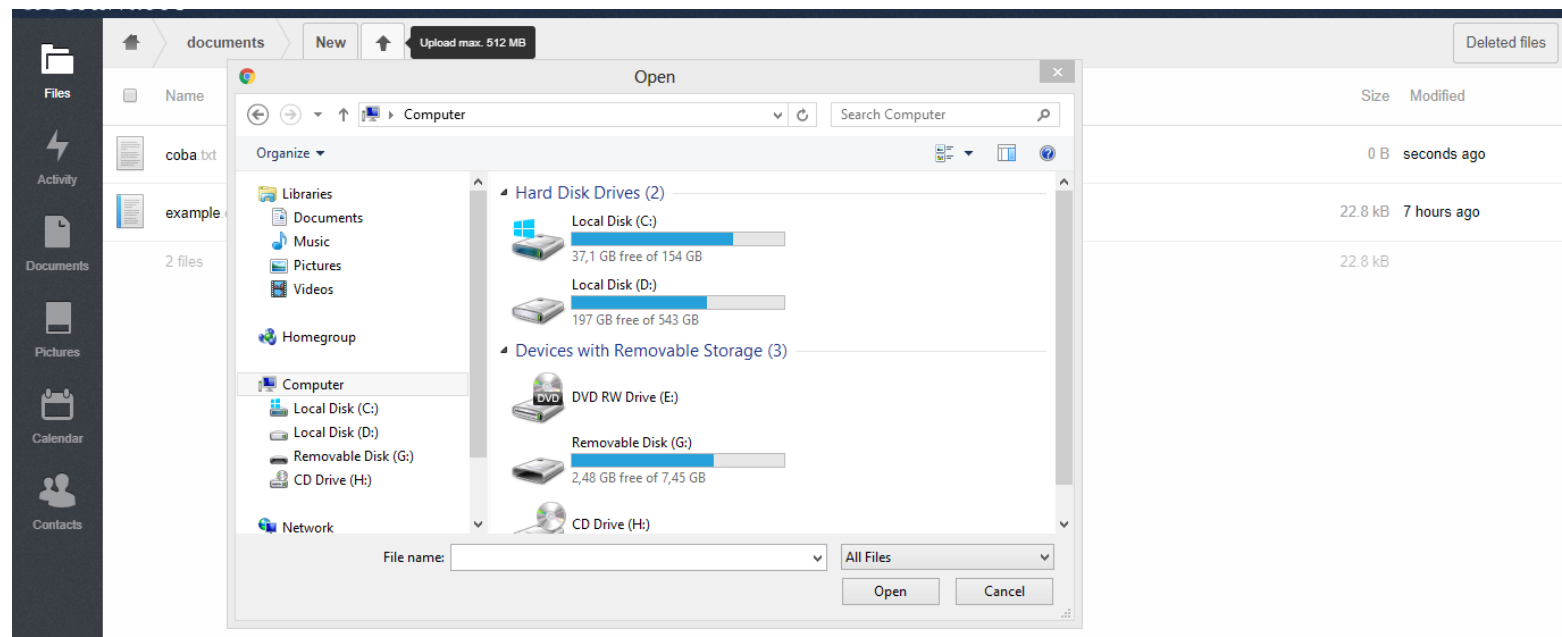

Gambar 6. Tampilan proses upload data di owncloud

4. Tampilan pada saat memilih data pada umumnya.

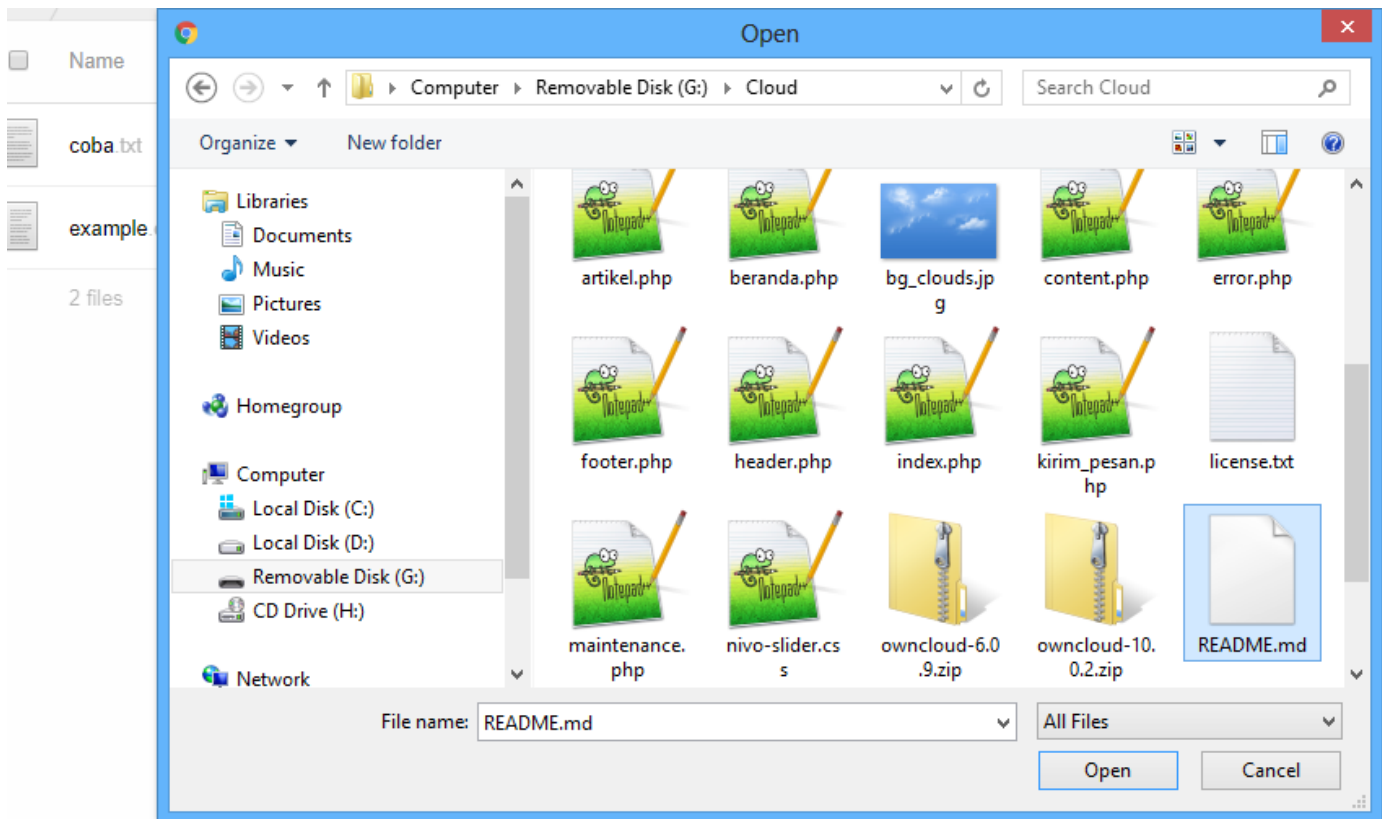

Gambar 7. Tampilan proses pemilihan data pada komputer 
5. Tampilan setelah data masuk ke dalam cloud.

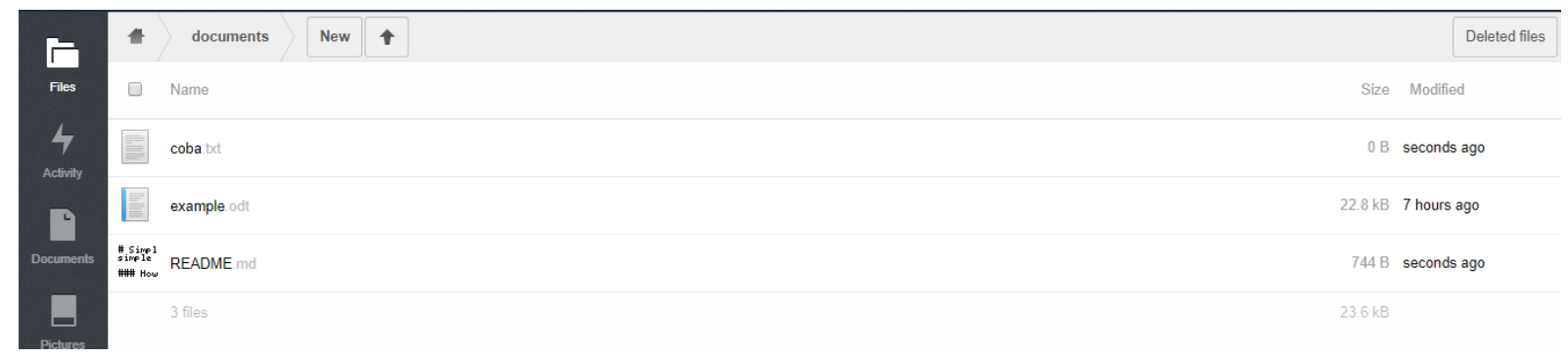

Gambar 8. Tampilan setelah data masuk ke dalam cloud

\subsection{Pengujian (Testing)}

Berdasarkan perangkat yang digunakan untuk penerapan cloud pada objek penelitian mendapatkan hasil testing yang cukup baik, berikut spesifikasi perangkat yang digunakan: Komputer yang digunakan:

Tabel 1. Perangkat yang digunakan

\begin{tabular}{llll}
\hline \multicolumn{4}{c}{ KOMPUTER YANG DIGUNAKAN } \\
\hline SERVER 1 & CLIENT 1 & CLIENT 2 & CLIENT 3 \\
\hline 1 komputer & 10 komputer & 13 komputer & 2 komputer \\
personal & personal & personal & personal \\
Core i5 1,8Ghz & Core i3 1,8Ghz & Dual core 1,8Ghz & Pentium 4 \\
RAM 8Gb & RAM 2Gb & RAM 2Gb & RAM 1Gb \\
64-bit Operating & 64-bit Operating & 64-bit Operating & 32-bit Operating \\
System & System & System & System \\
Windows 7 & Windows 7 & Windows 7 & Windows XP \\
UPS & & & \\
\hline
\end{tabular}

Hasil testing meliputi Performa, Kecepatan akses, dan Keakuratan pada PC client:

Tabel 2. Aspek pengujian

\begin{tabular}{|c|c|c|c|}
\hline Komputer & Performa & $\begin{array}{c}\text { Kecepatan } \\
\text { Akses }\end{array}$ & Keakuratan \\
\hline Client 1 (10 PC) & Sangat Baik & 100Mbps & $\begin{array}{l}\text { Tidak terjadi } \\
\text { error }\end{array}$ \\
\hline Client 2 (13 PC) & Baik & 100Mbps & $\begin{array}{l}\text { Tidak terjadi } \\
\text { error }\end{array}$ \\
\hline Client 3 (2 PC) & Cukup Baik & 40Mbps & $\begin{array}{l}\text { Tidak terjadi } \\
\text { error }\end{array}$ \\
\hline
\end{tabular}

Hasil testing kelayakan terhadap server meliputi Memory Hard disk, RAM, Akses, kemudahan akses: 
Tabel 3. Hasil yang dicapai

\begin{tabular}{llllll}
\hline Komputer & $\begin{array}{l}\text { Memory } \\
\text { Hard disk }\end{array}$ & RAM & Akses & $\begin{array}{l}\text { Kemudahan } \\
\text { Akses }\end{array}$ & $\begin{array}{l}\text { Waktu } \\
\text { Akses }\end{array}$ \\
\hline Pc core i5 & $1 \mathrm{~Tb}$ & $8 \mathrm{~Gb}$ & Upto & $\begin{array}{l}\text { Akses dapat } \\
\text { dengan }\end{array}$ & $\begin{array}{l}\text { Upto 24 } \\
\text { Jam }\end{array}$ \\
& & & $100 \mathrm{Mbps}$ & \\
& & & & browser & \\
\hline
\end{tabular}

Hasil testing yang dilakukan pada laboratorium komputer objek penelitian dengan keadaan seluruh komputer menyala dan mengakses secara bersamaan, PC server tidak down dan tetap berjalan dengan baik tanpa kendala dalam hal akses. Transfer data dapat berjalan dengan lancar tidak terjadi bug. Dapat pula diakses dengan PC di luar Lab dengan spesifikasi Pentium 4.

\section{PENUTUP}

\subsection{Kesimpulan}

Berdasarkan hasil penelitian dapat disimpulkan bahwa sistem informasi ini telah dibangun dengan teknik pengembangan sistem menggunakan model incremental yang merupakan model dengan manajemen sederhana, yaitu terdiri dari tahapan requirement, spesification, architecture design, code dan test, sehingga cocok untuk diterapkan dengan pembangunan sistem yang berbasis website.

Pada penelitian ini telah dijelaskan bagaimana Cloud Storage terbentuk. Terdapat empat tahapan, yaitu: pengecekan ketersediaan sumber daya, pengecekan ketersediaan image untuk server, running instance dan terminate instance.

Hasil uji diperoleh data hasil uji terhadap fungsionalitas sistem menunjukkan bahwa cloud yang dibangun telah sesuai dengan kebutuhan pengguna; untuk uji kinerja sistem, efisiensi diperoleh pada parameter setup time yaitu 23.33 menit lebih cepat dibandingkan sistem non cloud.

Untuk ability dapat menyediakan 4 server virtual sementara sistem non cloud hanya 2 server; dan access area yang lebih luas. IaaS yang dibangun memiliki kekurangan pada respon time yaitu 2.33 detik lebih lambat dibandingkan sistem non cloud dan package install yang kurang fleksibel karena harus selalu terkoneksi repository internet.

\subsection{Saran}

Untuk penelitian selanjutnya, perlu dikembangkan layanan IaaS untuk web hosting, storage service, disaster recovery and backup service, serta networking service; fleksibilitas akses dengan menggunakan Wireless Local Area Network (WLAN); serta penambahan fitur akses Virtual Private Network (VPN) untuk mengelola hak akses. Eksperimen selanjutnya sangat dimungkinkan untuk dilakukan pada sektor yang lain seperti pada sektor industri atau pada lembaga pemerintahan.

\section{DAFTAR PUSTAKA}

[1] Anggeriana, Herwin, 2011, Cloud Computing, Jurnal Teknik Informatika, Vol 1 September 2011

[2] Arikunto, S., 2009, Manajemen Penelitian, Penerbit Rineka Cipta, Jakarta

[3] Azuma, Ronald T. 1997. A Survey of Cloud Computing, Hughes Research Laboratories, Malibu

[4] Danto, Walesa, 2011, Analisis Metode Occlusion Based Pada Augmented Reality Studi Kasus: Interaksi Dengan Objek Virtual Secara Real Time Menggunakan Gerakan Marker, SNASTIA 2011-01-10

[5] Domhan, Tobias. 2010. Cloud Server on Android Smartphone, Dualen Hochschule Baden-Württemberg, Jerman.

[6] Hardiansyah, Fadilah Fahrul, 2012, Pemanfaatan Cloud Server Untuk Fasilitas Umum Berbasis Android, Institut Teknologi Sepuluh Nopember

[7] Qi, Han dan Abdullah Gani, 2012, Research on Mobile Cloud Computing: Review, Trend and Perspectives, Faculty of Computer Science and Information Technology, University of Malaya, Kuala Lumpur, Malaysia

[8] Ruei Huang, Bai, 2012, Mobile Augmented Reality Based on Cloud 
Computing, National Taiwan University of Science and Technology

[9] Safaat, Nazrudin. 2011. Pemrograman Aplikasi Mobile Smartphone dan Tablet $P C$ Berbasis Android. Bandung: Informatika 